INDIAN INSTITUTE OF MANAGEMENT AHMEDABAD

\title{
IIMA
}

Working Paper

Central bank gold reserves and sovereign credit risk

Sawan Rathi

Sanket Mohapatra

Arvind Sahay

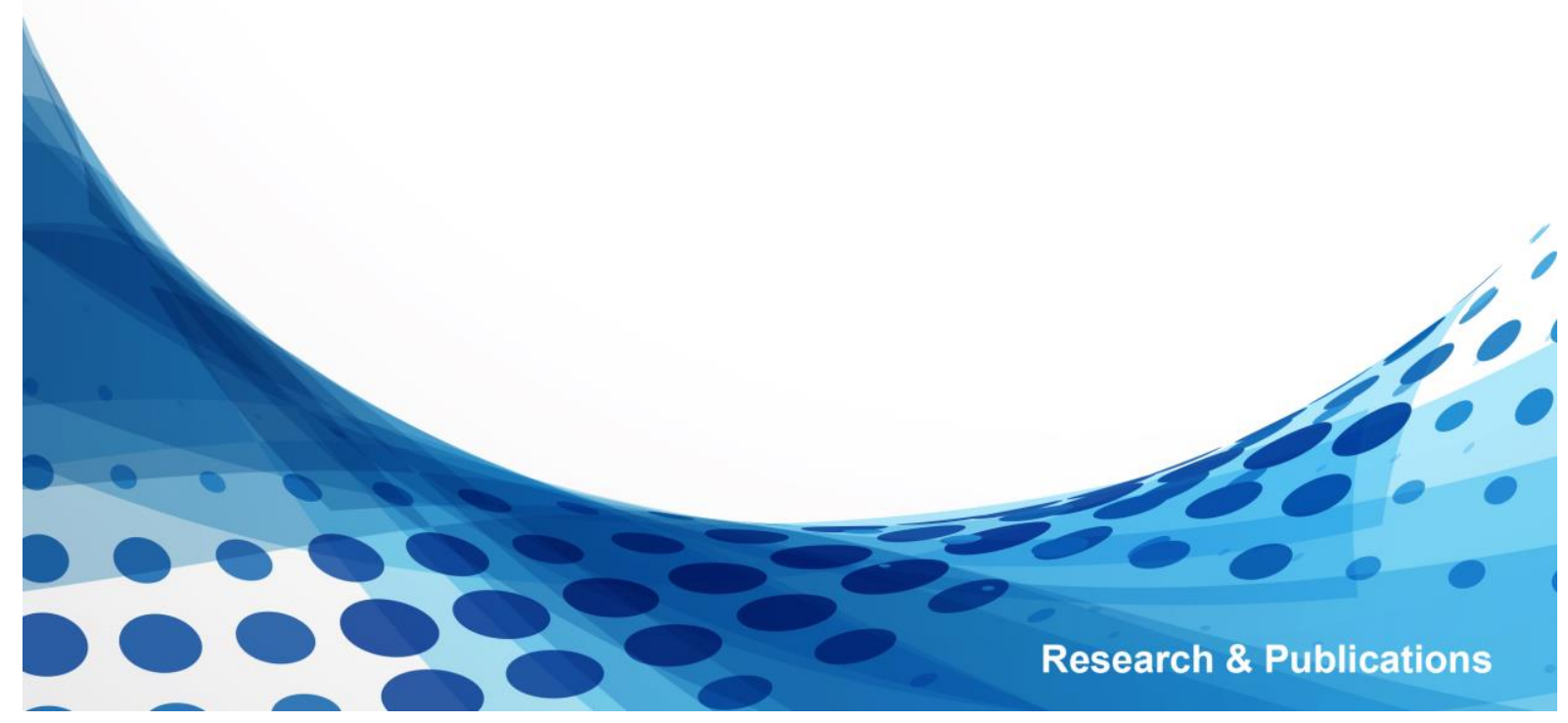




\section{Central bank gold reserves and sovereign credit risk}

Sawan Rathi

Sanket Mohapatra

Arvind Sahay

March 2021

The main objective of the working paper series of the IIMA is to help faculty members, research staff and doctoral students to speedily share their research findings with professional colleagues and test their research findings at the pre-publication stage. IIMA is committed to maintain academic freedom. The opinion(s), view(s) and conclusion(s) expressed in the working paper are those of the authors and not that of IIMA. 


\title{
Central bank gold reserves and sovereign credit risk ${ }^{*}$
}

\author{
Sawan Rathi $†$ Sanket Mohapatra $\ddagger$ and Arvind Sahay ${ }^{\S}$
}

\begin{abstract}
Gold holdings with central banks are often considered to play a stabilizing role in times of crisis. This paper performs a cross-country panel data analysis of developed and developing countries to determine whether gold holdings of central banks contribute to sovereign creditworthiness. Our analysis confirms that an increase in central bank gold reserves reduces the credit default swap (CDS) spreads of a country. We also observe that during global crisis and country-specific crisis episodes, the role of central bank gold becomes even more important. In robustness tests, we account for potential endogeneity of central bank gold reserves using a Generalized Method of Moments (GMM) approach. The findings highlight the importance of gold in central bank reserves and indicate a positive role of gold in mitigating a nation's external vulnerabilities in an uncertain global economic environment.
\end{abstract}

Keywords: Central bank gold reserves; Country risk; Credit default swap spreads JEL Codes: E58; G01; G11

*This paper has benefited from comments and suggestions from Abhiman Das, Balagopal Gopalakrishnan, Sudheesh Nambiath, and participants at the IGPC-IIMA Gold and Gold Markets Conference 2021. The authors would like to thank Minal Marathe of the India Gold Policy Centre for assistance with data. Funding from IIM Ahmedabad and UTI AMC is acknowledged.

${ }^{\dagger}$ Economics Area, MSH-102, New Campus, Indian Institute of Management Ahmedabad, Gujarat, India, 380015. Email: phd19sawanr@iima.ac.in

${ }^{\ddagger}$ Economics Area, Room 35, KLMDC, Heritage Campus, Indian Institute of Management Ahmedabad, Gujarat, India, 380015. Email: sanketm@iima.ac.in

$\S$ Marketing Area, Room 3, KLMDC, Heritage Campus, Indian Institute of Management Ahmedabad, Gujarat, India, 380015. Email: asahay@iima.ac.in 


\section{Introduction}

Since the gold standard era, until today, gold has been looked upon as money, as an investment, as a store, and as a source of value. Gold acts as a 'safe haven' asset in times of global turbulence (Baur \& Lucey, 2010). The long and intertwined history of gold, money, and financial markets has resulted in gold's regular prominence in monetary and investment discussions (O’Connor, Lucey, Batten, \& Baur, 2015). Gold can be especially effective during times of stress because of the negative correlation of gold with equities (Lucey, Peat, Šević, \& Vigne, 2021) and low correlation with other financial assets (WGC, 2016), making it very effective at diversifying a portfolio and reducing its inherent risk and volatility. Gold is an important component of central banks' reserve portfolios in advanced economies (Aizenman \& Inoue, 2013) and emerging markets (Gopalakrishnan \& Mohapatra, 2018).

Monnet and Puy (2020) study how gold standard practices survived among monetary authorities after the Second World War (WWII), although the Bretton Woods agreement, the aftermath of the Great Depression, and the shock of the war were supposed to have eliminated these practices. Ghosh (2016) finds that the rationale for holding gold in the central bank's reserves is no different from that of individual investors or hedge fund managers. Gold has been found to be both a hedge and a safe haven for domestic investors in most countries (Gürgün \& Ünalmış, 2014). Bordo (1996) finds that adherence to gold standard rules acted as a 'seal of approval' for sovereign debt. Gold standard countries had lower country risk, measured by their bond spreads in London relative to the British consol (Obstfeld \& Taylor, 2003).

The positive role of gold documented in the literature suggests that central bank gold reserves may mitigate sovereign credit risk, particularly during crisis episodes. We use sovereign credit default swap (CDS) spreads as the measure of country risk in this study. The CDS is a standard instrument offering the possibility of hedging against default by the issuer of an underlying bond (Hull \& White, 2000). The state of countries' and the world's financial systems have strong explanatory power for the behavior of CDS spreads (Dieckmann \& Plank, 2012). Sovereign CDS spreads convey direct information on the importance of global and domestic risk factors for the dynamics of sovereign credit risk compared to sovereign debt spreads (Ang 
\& Longstaff, 2013; Augustin, 2018). Trading activity in the CDS contracts of sovereign issuers has reached a point that the CDS market is more liquid than that of many underlying bonds (Pan \& Singleton, 2008).

This study analyzes whether gold holdings with central banks can aid in reducing a country's risk measured by CDS spreads. We conduct a panel data analysis for 48 developing and developed countries using annual data. We control for a variety of country-level macroeconomic and institutional factors and global risk in the estimations. We also examine the effect of central gold holdings on country risk during episodes of high global volatility, as well as country-specific debt crisis, inflation crisis and currency crisis episodes. To the best of our knowledge, this is the first study to conduct a cross-country empirical analysis of the effect of gold holdings by central banks on sovereign credit risk. We contribute to the existing literature and show that increased gold holdings with central banks not only help to reduce country risk during normal times but also mitigates the effect of crisis on sovereign creditworthiness.

\section{Data and Methodology}

\subsection{Data}

The study uses five-year sovereign CDS spreads obtained from the Bloomberg database from 2000 until 2020. Data on central banks' gold stocks (in troy ounces) is obtained from the World Gold Council (WGC) database. The panel data analysis uses annual averages of sovereign CDS spreads and central bank gold holdings. A scatterplot of sovereign CDS spreads and the corresponding central bank gold reserves shows a broadly negative relationship (Figure 1). A more systematic analysis of this relationship is conducted after accounting for various other factors that can influence sovereign CDS spreads as described below.

We control for various country-level and global factors that can influence a country's sovereign risk (Edwards, 1983; Rodríguez, Dandapani, \& Lawrence, 2019) in the estimations. Data on country-level controls, namely, GDP per capita, inflation, current account balance, GDP growth, and total reserves (excluding gold) as a percentage of imports, are obtained primarily from the World Bank's World Development Indicators (WDI) database. The IMF's World 
Economic Outlook database is used to obtain sovereign debt as a percentage of GDP and fiscal balance as a percentage of GDP for each country. Also, country-specific governance parameters are controlled for using the Rule of Law variable from the World Bank's World Governance Index (WGI) database compiled by (Kaufmann, Kraay, \& Mastruzzi, 2011).

Finally, due to interconnections between financial markets worldwide, it's important to control for episodes of heightened global volatility (Mauro, Sussman, \& Yafeh, 2002). We include an indicator, HighVIX, for the years when the Chicago Board Options Exchange's (CBOE) volatility index, or VIX index, is in the top 10 percentile for at least two quarters of the year during 2000-2020. The HighVIX indicator captures two major economic crisis events, the Global Financial Crisis in 2008-09 and the COVID-19 crisis in 2020 (see shaded region in Figure 2). To examine the effect of central bank gold in times of crisis, we use the global HighVIX measure and country-specific data on debt crisis, inflation crisis, and currency crisis from the Harvard Business School's Global Crisis database (Ilzetzki, Reinhart, \& Rogoff, 2017). Details of variable construction and summary statistics of the variables are shown in Table 1.

\subsection{Empirical Methodology}

The relationship between sovereign CDS spreads and central bank gold holdings is estimated using a cross-country panel of developed and developing countries. The estimation equation is as follows:

$$
\log _{\mathbf{C D S}} \mathbf{i}_{\mathbf{t}}=\alpha+\beta \log \operatorname{CBGold}_{\mathbf{i}, \mathbf{t}-\mathbf{1}}+\gamma \mathbf{C}_{\mathbf{i}, \mathbf{t}-\mathbf{1}}+\delta \mathbf{G}_{\mathbf{t}}+\mu_{i}+\tau_{t}+\epsilon_{i, t}
$$

The dependent variable $\log C D S_{i, t}$ is the logarithm of the average sovereign CDS spreads of country $i$ in year $t$. The key explanatory variable of interest $\log C B G o l d_{i, t-1}$ is the previous year's central bank gold holdings in troy ounces. Using the lagged value of $\log C B G$ Gold in the estimation helps in mitigating possible contemporaneous feedback effects. $C_{i, t-1}$ is the set of lagged country-specific macroeconomic control variables for country $i$ at time $t-1$. $G_{t}$ is the global risk variable. Country fixed effects $\left(\mu_{i}\right)$ are included to control for unobserved time-invariant heterogeneity across countries. Year fixed effects $\left(\tau_{t}\right)$ account for time-varying 
common shocks in some specifications. A negative and significant coefficient of $\log C B G$ Gold $(\beta)$ would imply that higher gold holdings of a central bank reduces the country's credit risk.

In further analysis, we consider the effect of central bank gold holdings during global and country-specific crisis episodes. The LogCBGold is interacted with a variety of indicators of financial turmoil and crisis. These include periods of high financial market volatility (as measured by the HighVIX index) and country-specific debt crisis, inflation crisis and currency crisis episodes. The following equation is estimated to measure the incremental effect of central bank gold holdings on sovereign CDS spreads during crisis episodes:

$$
\begin{gathered}
\operatorname{LogCDS}_{\mathbf{i}, \mathbf{t}}=\alpha+\beta \text { LogCBGold }_{\mathbf{i}, \mathbf{t}-\mathbf{1}}+\zeta \text { LogCBGold }_{\mathbf{i}, \mathbf{t}-\mathbf{1}} \times \text { Crisis }_{\mathbf{i}, \mathbf{t}} \\
+\gamma \mathbf{C}_{\mathbf{i}, \mathbf{t}-\mathbf{1}}+\delta \mathbf{G}_{\mathbf{t}}+\mu_{i}+\tau_{t}+\epsilon_{i, t}
\end{gathered}
$$

\section{Results}

\subsection{Baseline Results}

The results of the estimation of Equation 1, where the dependent variable is $\log C D S$, are presented in Table 2. All columns include central bank gold holdings ( $\log C B G$ Gold) as the explanatory variable of interest. Column (1) presents the baseline relationship of gold holdings with CDS spreads without any controls. In columns (2) and (3), we gradually introduce country-level macroeconomic controls. In columns (4) and (5), we add the high volatility (HighVIX) variable, which is common across countries, but remove year fixed effects. All the estimations include country-fixed effects to account for time-invariant heterogeneity across countries.

The results in columns (1)-(5) show that sovereign CDS spreads have a negative and significant association with the central bank gold holdings of a country. We find that, depending on the set of controls employed, the elasticity of sovereign CDS spreads to overall central bank gold ranges from -0.12 to -0.32 . In other words, a $10 \%$ increase in central bank gold reserves is associated with a $1.2 \%$ to $3.2 \%$ decrease in CDS spreads.

The results for the country-specific macroeconomic control variables further indicate that 
$\log C D S$ is negatively associated with GDP growth. The negative and statistically significant association for fiscal balance and international reserves (excluding gold) is as expected, since higher fiscal strength and larger foreign exchange reserves can result in reduced sovereign credit risk. CDS spreads are positively associated with higher sovereign debt as a percentage of GDP, as higher debt is usually associated with greater risk of debt default of a country. The negative sign of the governance indicator, Rule of Law, suggests that a better institutional environment is associated with lower sovereign risk. Finally, sovereign CDS spreads are positively related to the high global volatility index, HighVIX, indicating that sovereign risk is associated with higher volatility in the global financial markets. The relationship of CDS spreads with GDP per capita, current account balance as a \% of GDP and inflation are not significant.

\subsection{Heterogeneous impacts during crisis}

Next, we investigate whether the negative association between central bank gold reserves and sovereign CDS spreads varies during high volatility and crisis periods. The results of the estimation of Equation 2 are shown in Table 3. In column (1), we interact central bank gold with HighVIX. In columns (2), (3), and (4), the interaction is with debt crisis, inflation crisis, and currency crisis indicators, respectively. In all models, we use country-specific control variables similar to the one used in the baseline results. All estimations include country-fixed effects. Year fixed effects are applied in all estimations except column (1).

The negative relationship of central bank gold in all columns of Table 3 is similar to our baseline results. Moreover, the interaction terms for crisis are also significant in the first three columns. Considering the base effect of LogCBGold and the interaction with crisis, the results indicate that in periods of high volatility, a $10 \%$ increase in overall CB gold causes a $4.0 \%$ decrease in sovereign CDS spreads, compared to a 3.1\% decline in other periods (column (1)). During debt crisis, a 10\% increase in overall CB gold causes a $13.3 \%$ decrease in sovereign CDS spreads, compared to 3.0\% decline in other periods (column (2)). During inflation crisis, a $10 \%$ increase in overall CB gold causes a $16.0 \%$ decrease in sovereign CDS spreads, compared to $3.2 \%$ decline in other periods (column (3)). The results for the currency crisis interaction is also negative but not significant. 


\subsection{GMM estimation: Accounting for potential endogeneity}

In this section, we consider possible endogeneity of gold holdings by central banks to sovereign CDS spreads. Our earlier analysis showed that central banks' gold holdings attenuate a country's credit risk. But it is also possible that higher country risk can encourage central banks to purchase gold. Moreover, CDS spreads may be persistent over time, which can bias our estimates. In light of these two issues, we use a dynamic two-step GMM estimation (Arellano \& Bover, 1995; Blundell \& Bond, 1998; Windmeijer, 2005). With N (48) > T (20), where N and $\mathrm{T}$ are the number of countries and time periods, respectively, this methodology is appropriate. The second lags of LogCDS and LogCBGold are used as instruments in the estimations.

The results shown in Table 4 show that the elasticity of sovereign CDS spreads in response to a percentage change in central bank gold holdings ranges from -0.16 to -0.27 . This is similar to the results obtained from our baseline panel estimation. The control variables also show the same sign and significance. Thus, the results of the dynamic GMM estimation strengthens our claim of the negative association between central bank gold reserves and sovereign risk.

\section{Conclusion}

Using panel data for 48 developing and developed countries, we show that gold reserves with central banks can be beneficial for a country's sovereign creditworthiness. Our baseline results show that when central bank reserves rise, sovereign CDS spreads tend to decrease, indicating reduced country risk. Moreover, estimations with a high global volatility measure and countrylevel crisis indicators show that gold's importance increases during crisis episodes. We address possible endogeneity concerns with the GMM estimation method, which provides evidence consistent with our baseline results.

Overall, the finding of this study suggest that central bank gold reserves can play a stabilizing role for a nation's external position. Our study contributes to the literature on role of gold holdings of central banks and the diversification of international reserves. Given an uncertain global economic recovery after COVID-19, diversifying central bank portfolios with higher gold reserves may help in providing a cushion against future macroeconomic shocks. 


\section{References}

Aizenman, J., \& Inoue, K. (2013). Central banks and gold puzzles. Journal of the Japanese and International Economies, 28, 69-90.

Ang, A., \& Longstaff, F. A. (2013). Systemic sovereign credit risk: Lessons from the US and Europe. Journal of Monetary Economics, 60(5), 493-510.

Arellano, M., \& Bover, O. (1995). Another look at the instrumental variable estimation of error-components models. Journal of Econometrics, 68(1), 29-51.

Augustin, P. (2018). The term structure of CDS spreads and sovereign credit risk. Journal of Monetary Economics, 96, 53-76.

Baur, D. G., \& Lucey, B. M. (2010). Is gold a hedge or a safe haven? an analysis of stocks, bonds and gold. Financial Review, 45(2), 217-229.

Blundell, R., \& Bond, S. (1998). Initial conditions and moment restrictions in dynamic panel data models. Journal of Econometrics, 87(1), 115-143.

Bordo, R. (1996). The gold standard as a 'good housekeeping seal of approval'. The Journal of Economic History, 56, 389.

Dieckmann, S., \& Plank, T. (2012). Default risk of advanced economies: An empirical analysis of credit default swaps during the financial crisis. Review of Finance, 16(4), 903-934.

Edwards, S. (1983). LDCś foreign borrowing and default risk: An empirical investigation. National Bureau of Economic Research, No.w1172.

Ghosh, A. (2016). What drives gold demand in central bank's foreign exchange reserve portfolio? Finance Research Letters, 17, 146-150.

Gopalakrishnan, B., \& Mohapatra, S. (2018). Turning over a golden leaf? Global liquidity and emerging market central banks' demand for gold after the financial crisis. Journal of International Financial Markets, Institutions and Money, 57, 94-109.

Gürgün, G., \& Ünalmış, İ. (2014). Is gold a safe haven against equity market investment in emerging and developing countries? Finance Research Letters, 11(4), 341-348.

Hull, J. C., \& White, A. D. (2000). Valuing credit default swaps: No counterparty default risk. The Journal of Derivatives, 8(1), 29-40.

Ilzetzki, E., Reinhart, C. M., \& Rogoff, K. S. (2017). The Country Chronologies to Exchange 
Rate Arrangements into the 21st Century: Will the anchor currency hold? National Bureau of Economic Research, No. w23135.

Kaufmann, D., Kraay, A., \& Mastruzzi, M. (2011). The Worldwide Governance Indicators: Methodology and Analytical Issues. Hague Journal On The Rule Of Law, 3(2), 220-246. Lucey, B. M., Peat, M., Šević, A., \& Vigne, S. A. (2021). What is the optimal weight for gold in a portfolio? Annals of Operations Research, 297, 277-291.

Mauro, P., Sussman, N., \& Yafeh, Y. (2002). Emerging market spreads: then versus now. The Quarterly Journal of Economics, 117(2), 695-733.

Monnet, E., \& Puy, D. (2020). Do old habits die hard? Central Banks and the Bretton Woods gold puzzle. Journal of International Economics, 127, 103394.

Obstfeld, M., \& Taylor, A. M. (2003). Sovereign risk, credibility and the gold standard: 18701913 versus 1925-31. The Economic Journal, 113(487), 241-275.

O’Connor, F. A., Lucey, B. M., Batten, J. A., \& Baur, D. G. (2015). The financial economics of gold-a survey. International Review of Financial Analysis, 41, 186-205.

Pan, J., \& Singleton, K. J. (2008). Default and recovery implicit in the term structure of sovereign CDS spreads. The Journal of Finance, 63(5), 2345-2384.

Rodríguez, I. M., Dandapani, K., \& Lawrence, E. R. (2019). Measuring sovereign risk: Are CDS spreads better than sovereign credit ratings? Financial Management, 48(1), 229256.

WGC. (2016). Gold: Valuable reserve amid unprecedented policy environment.

Windmeijer, F. (2005). A finite sample correction for the variance of linear efficient two-step gmm estimators. Journal of Econometrics, 126(1), 25-51. 
Figure 1: Scatterplot of log CDS Spreads versus log Central Bank Gold

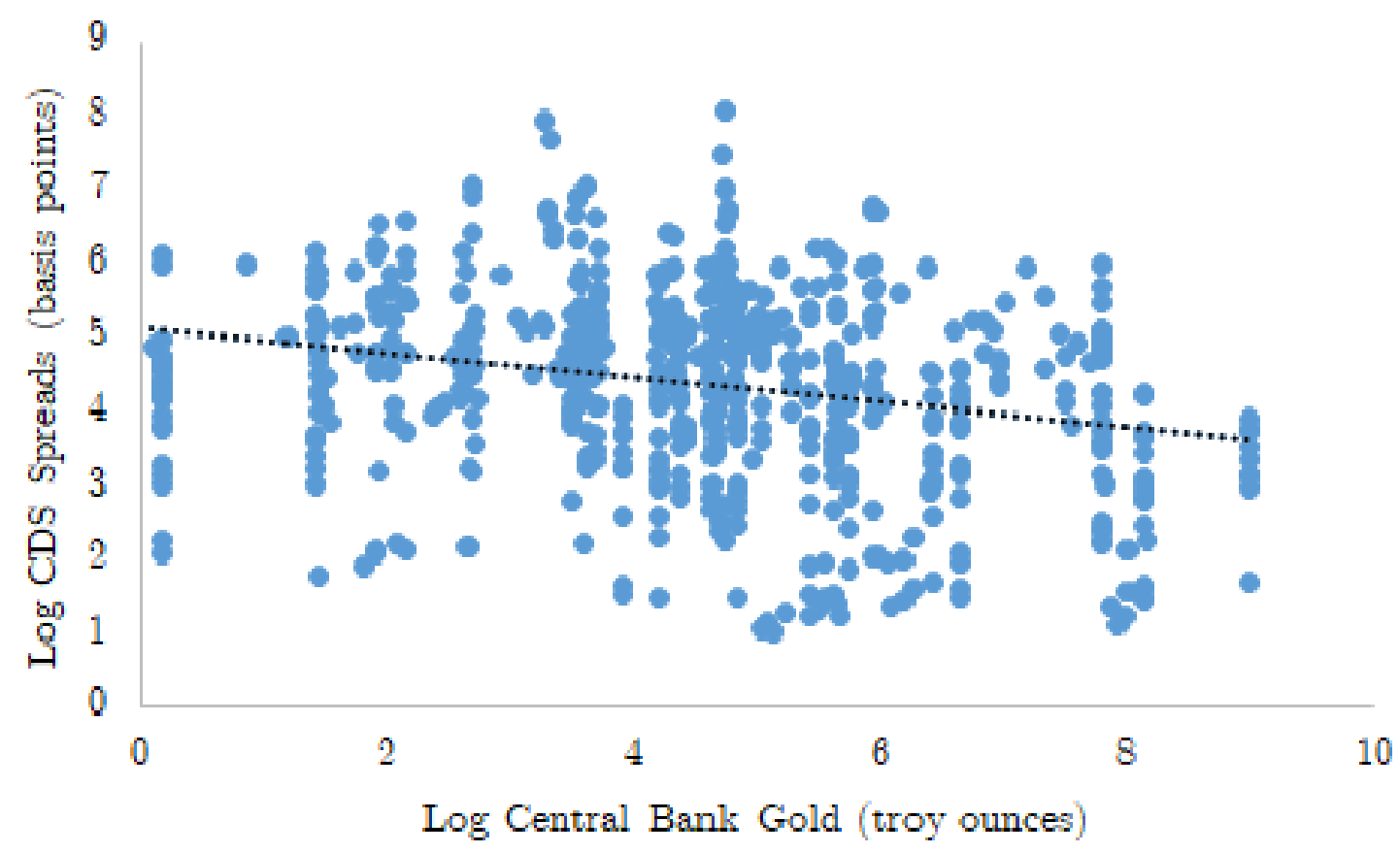

Figure 2: VIX Index for years 2000 to 2020, with shaded regions showing the HighVIX years

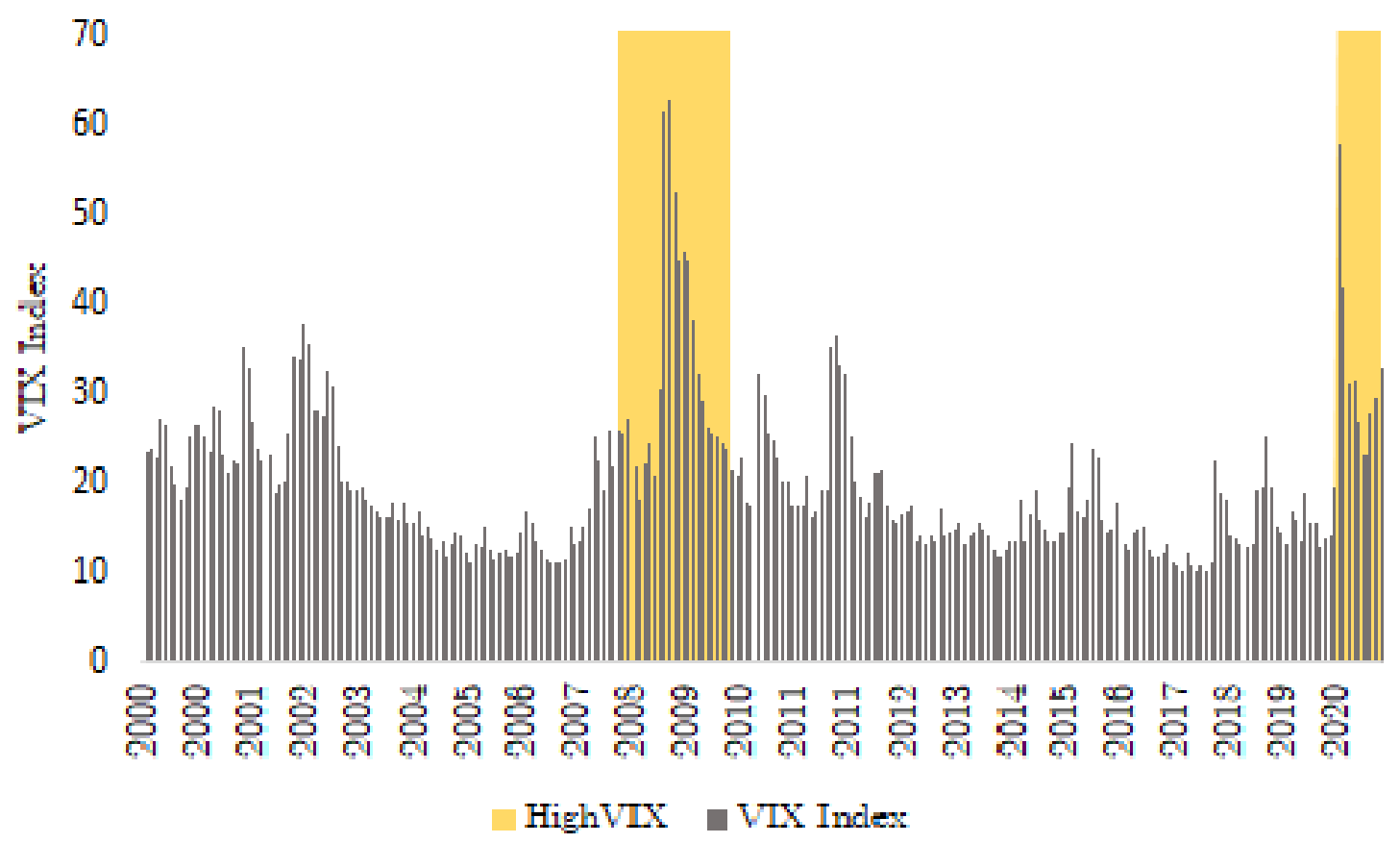


Table 1: Variable Description and Summary Statistics

\begin{tabular}{|c|c|c|c|c|c|c|c|c|}
\hline Variables & Definition and Construction & Data Source & $\mathbf{N}$ & Mean & St.Dev & Median & Min. & Max. \\
\hline $\log$ CDS & $\begin{array}{l}\text { Logarithm of five-year credit default swap (CDS) } \\
\text { spreads on sovereign debt (in basis points) }\end{array}$ & Bloomberg & 637 & 4.374 & 1.268 & 4.548 & 1.023 & 8.096 \\
\hline Log CB Gold & $\begin{array}{l}\text { Logarithm of gold holdings by the central bank of a } \\
\text { country (in troy ounces) }\end{array}$ & World Gold Council & 637 & 14.777 & 2.215 & 15.020 & 8.769 & 19.382 \\
\hline Log GDP per capita & Logarithm of GDP per capita (in current US\$) & World Bank WDI & 637 & 9.590 & 0.999 & 9.617 & 6.955 & 11.351 \\
\hline Fiscal balance $\%$ of GDP & $\begin{array}{l}\text { General government net lending/borrowing as percent- } \\
\text { age of GDP }\end{array}$ & $\begin{array}{l}\text { International Monetary } \\
\text { Fund }\end{array}$ & 637 & -2.348 & 3.506 & -2.436 & -15.141 & 21.560 \\
\hline Sovereign debt $\%$ of GDP & Central government debt as percentage of GDP & $\begin{array}{l}\text { International Monetary } \\
\text { Fund }\end{array}$ & 637 & 50.871 & 35.761 & 41.076 & 1.274 & 197.633 \\
\hline GDP growth $(\%)$ & $\begin{array}{l}\text { Percentage growth in GDP of a country calculated an- } \\
\text { nually }\end{array}$ & World Bank WDI & 637 & 2.666 & 3.520 & 2.554 & -14.814 & 14.231 \\
\hline Reserves as \% of imports & $\begin{array}{l}\text { Total central bank foreign exchange reserves (exclud- } \\
\text { ing gold) as percentage of imports }\end{array}$ & World Bank WDI & 637 & 43.471 & 44.926 & 34.645 & 0.289 & 255.289 \\
\hline Inflation (\%) & $\begin{array}{l}\text { Inflation in consumer prices in percentage calculated } \\
\text { annually }\end{array}$ & World Bank WDI & 637 & 3.549 & 4.446 & 2.583 & -10.067 & 54.400 \\
\hline Curr. Acc. Bal. \% of GDP & $\begin{array}{l}\text { Current account balance as percentage of GDP of a } \\
\text { country }\end{array}$ & World Bank WDI & 637 & -0.123 & 5.838 & -0.418 & -25.756 & 33.185 \\
\hline Rule of Law & WGI Rule of Law index & World Bank WGI & 637 & 0.620 & 0.867 & 0.734 & -1.838 & 2.100 \\
\hline HighVIX & $\begin{array}{l}\text { A year specific dummy variable that takes the value } 1 \\
\text { for all years in which the VIX index is in top } 10 \text { per- } \\
\text { centiles for at least two quarters of the year }\end{array}$ & $\begin{array}{l}\text { Authors' Calculations } \\
\text { based on CBOE VIX }\end{array}$ & 637 & 0.068 & 0.251 & 0.000 & 0.000 & 1.000 \\
\hline Debt Crisis & $\begin{array}{l}\text { A country-specific dummy variable that takes the value } \\
1 \text { for all the years in which there is a sovereign exter- } \\
\text { nal debt default in a country during 2000-2016 and } 0 \\
\text { otherwise. }\end{array}$ & $\begin{array}{l}\text { Behavioral Finance and } \\
\text { Financial Stability data } \\
\text { from Harvard Buisness } \\
\text { School }\end{array}$ & 395 & 0.008 & 0.087 & 0.000 & 0.000 & 1.000 \\
\hline Inflation Crisis & $\begin{array}{l}\text { A country-specific dummy variable that takes the value } \\
1 \text { for all the years in which annual inflation is } 40 \% \text { or } \\
\text { higher in a country during } 2000-2016 \text { and } 0 \text { otherwise. }\end{array}$ & $\begin{array}{l}\text { Behavioral Finance and } \\
\text { Financial Stability data } \\
\text { from Harvard Buisness } \\
\text { School }\end{array}$ & 395 & 0.008 & 0.087 & 0.000 & 0.000 & 1.000 \\
\hline Currency Crisis & $\begin{array}{l}\text { A country-specific dummy variable that takes the value } \\
1 \text { for all the years in which there is a currency crisis in } \\
\text { a country during } 2000-2016 \text { and } 0 \text { otherwise. }\end{array}$ & $\begin{array}{l}\text { Behavioral Finance and } \\
\text { Financial Stability data } \\
\text { from Harvard Buisness } \\
\text { School }\end{array}$ & 395 & 0.106 & 0.309 & 0.000 & 0.000 & 1.000 \\
\hline
\end{tabular}


Table 2: Central bank gold holdings and sovereign CDS spreads

The dependent variable in all columns is the logarithm of credit default swap (CDS) spreads on sovereign debt. All the explanatory variables, except for HighVIX, are lagged by one year. Robust standard errors, clustered at the country level, are presented in parentheses. '***', '**', '*' indicate significance at the 1\%, 5\% and $10 \%$ levels, respectively.

\begin{tabular}{|c|c|c|c|c|c|}
\hline & (1) & (2) & (3) & (4) & (5) \\
\hline Log CB Gold & $\begin{array}{c}-0.215^{* *} \\
(0.104)\end{array}$ & $\begin{array}{c}-0.118 * \\
(0.067)\end{array}$ & $\begin{array}{c}-0.137 * * \\
(0.059)\end{array}$ & $\begin{array}{c}-0.328 * \\
(0.178)\end{array}$ & $\begin{array}{l}-0.320^{*} \\
(0.161)\end{array}$ \\
\hline Log GDP per capita & & $\begin{array}{c}-0.481 \\
(0.303)\end{array}$ & $\begin{array}{l}-0.321 \\
(0.316)\end{array}$ & $\begin{array}{c}0.843 * * * \\
(0.174)\end{array}$ & $\begin{array}{c}0.951 * * * \\
(0.184)\end{array}$ \\
\hline Fiscal balance $\%$ of GDP & & $\begin{array}{c}-0.040^{* * *} \\
(0.015)\end{array}$ & $\begin{array}{c}-0.038 * * \\
(0.015)\end{array}$ & $\begin{array}{c}-0.070 * * \\
(0.031)\end{array}$ & $\begin{array}{c}-0.081 * * * \\
(0.028)\end{array}$ \\
\hline Sovereign debt $\%$ of GDP & & $\begin{array}{c}0.022 * * * \\
(0.004)\end{array}$ & $\begin{array}{c}0.022 * * * \\
(0.004)\end{array}$ & $\begin{array}{c}0.027 * * * \\
(0.004)\end{array}$ & $\begin{array}{c}0.025^{* * *} \\
(0.004)\end{array}$ \\
\hline GDP growth (\%) & & $\begin{array}{c}-0.035 * * \\
(0.014)\end{array}$ & $\begin{array}{c}-0.037 * * \\
(0.015)\end{array}$ & $\begin{array}{c}-0.062 * * * \\
(0.017)\end{array}$ & $\begin{array}{c}-0.058 * * * \\
(0.016)\end{array}$ \\
\hline Reserves as $\%$ of imports & & $\begin{array}{c}-0.011 * * * \\
(0.002)\end{array}$ & $\begin{array}{c}-0.011 * * * \\
(0.002)\end{array}$ & $\begin{array}{c}-0.012 * * * \\
(0.004)\end{array}$ & $\begin{array}{c}-0.013 * * * \\
(0.004)\end{array}$ \\
\hline Inflation $(\%)$ & & $\begin{array}{c}0.008 \\
(0.011)\end{array}$ & $\begin{array}{c}0.007 \\
(0.010)\end{array}$ & $\begin{array}{c}0.039 * * \\
(0.017)\end{array}$ & $\begin{array}{c}0.042 * * \\
(0.017)\end{array}$ \\
\hline Curr. Acc. Bal. \% of GDP & & & $\begin{array}{l}-0.009 \\
(0.007)\end{array}$ & & $\begin{array}{c}0.014 \\
(0.010)\end{array}$ \\
\hline Rule of Law & & & $\begin{array}{c}-0.775 * * \\
(0.311)\end{array}$ & & $\begin{array}{c}-0.986 * * \\
(0.417)\end{array}$ \\
\hline HighVIX & & & & $\begin{array}{c}0.953 * * * \\
(0.117)\end{array}$ & $\begin{array}{c}0.949 * * * \\
(0.112)\end{array}$ \\
\hline Observations & 637 & 637 & 637 & 637 & 637 \\
\hline Countries & 48 & 48 & 48 & 48 & 48 \\
\hline Country Fixed Effects & Yes & Yes & Yes & Yes & Yes \\
\hline Year Fixed Effects & Yes & Yes & Yes & No & No \\
\hline Adjusted R-squared & 0.564 & 0.739 & 0.746 & 0.360 & 0.373 \\
\hline
\end{tabular}


Table 3: Heterogeneous impacts during crisis

The dependent variable in all columns is the logarithm of credit default swap (CDS) spreads on sovereign debt. Columns (1)-(4) present the interaction of Log CB Gold with HighVIX, Debt Crisis, Inflation Crisis and Currency Crisis respectively. All the explanatory variables, except for HighVIX and crisis indicators, are lagged by one year. Robust standard errors, clustered at the country level, are presented in parentheses. '***', '**', '*' indicate significance at the $1 \%, 5 \%$ and $10 \%$ levels, respectively.

\section{HighVIX Int. Debt Crisis Int. Inflation Crisis Int. Ccy Crisis Int.}

$$
\text { (1) }
$$

\begin{tabular}{|c|c|c|c|c|}
\hline HighVIX x Log CB Gold & $\begin{array}{c}-0.091^{*} \\
(0.054)\end{array}$ & & & \\
\hline Debt Crisis x Log CB Gold & & $\begin{array}{c}-1.030 * * * \\
(0.163)\end{array}$ & & \\
\hline Inflation Crisis x Log CB Gold & & & $\begin{array}{c}-1.293 * * \\
(0.536)\end{array}$ & \\
\hline Currency Crisis x Log CB Gold & & & & $\begin{array}{l}-0.044 \\
(0.040)\end{array}$ \\
\hline Log CB Gold & $\begin{array}{l}-0.314^{*} \\
(0.163)\end{array}$ & $\begin{array}{c}-0.300 * * * \\
(0.082)\end{array}$ & $\begin{array}{c}-0.315^{* * * *} \\
(0.077)\end{array}$ & $\begin{array}{c}-0.293 * * * * \\
(0.081)\end{array}$ \\
\hline Log GDP per capita & $\begin{array}{c}0.949 * * * \\
(0.184)\end{array}$ & $\begin{array}{l}-0.476 \\
(0.421)\end{array}$ & $\begin{array}{l}-0.486 \\
(0.442)\end{array}$ & $\begin{array}{l}-0.453 \\
(0.430)\end{array}$ \\
\hline Fiscal balance $\%$ of GDP & $\begin{array}{c}-0.081 * * * \\
(0.028)\end{array}$ & $\begin{array}{c}-0.052 * * \\
(0.023)\end{array}$ & $\begin{array}{c}-0.046^{* *} \\
(0.021)\end{array}$ & $\begin{array}{c}-0.047 * * \\
(0.021)\end{array}$ \\
\hline Sovereign debt $\%$ of GDP & $\begin{array}{c}0.025^{* * * *} \\
(0.004)\end{array}$ & $\begin{array}{c}0.027 * * * \\
(0.007)\end{array}$ & $\begin{array}{c}0.030 * * * \\
(0.007)\end{array}$ & $\begin{array}{c}0.029 * * * \\
(0.007)\end{array}$ \\
\hline GDP growth (\%) & $\begin{array}{c}-0.058 * * * \\
(0.016)\end{array}$ & $\begin{array}{c}-0.044 * * \\
(0.019)\end{array}$ & $\begin{array}{c}-0.043^{* *} \\
(0.020)\end{array}$ & $\begin{array}{c}-0.049 * * \\
(0.019)\end{array}$ \\
\hline Reserves as $\%$ of imports & $\begin{array}{c}-0.013 * * * \\
(0.004)\end{array}$ & $\begin{array}{c}-0.011 * * \\
(0.004)\end{array}$ & $\begin{array}{c}-0.012 * * * \\
(0.004)\end{array}$ & $\begin{array}{c}-0.011 * * \\
(0.004)\end{array}$ \\
\hline Inflation (\%) & $\begin{array}{c}0.042 * * \\
(0.017)\end{array}$ & $\begin{array}{l}0.011 * \\
(0.006)\end{array}$ & $\begin{array}{c}0.012 \\
(0.016)\end{array}$ & $\begin{array}{c}0.010 \\
(0.006)\end{array}$ \\
\hline Curr. Acc. Bal. \% of GDP & $\begin{array}{c}0.015 \\
(0.010)\end{array}$ & $\begin{array}{c}-0.028^{*} \\
(0.016)\end{array}$ & $\begin{array}{l}-0.025 \\
(0.015)\end{array}$ & $\begin{array}{l}-0.030^{*} \\
(0.015)\end{array}$ \\
\hline Rule of Law & $\begin{array}{c}-0.987 * * \\
(0.418)\end{array}$ & $\begin{array}{c}-0.880 * * \\
(0.409)\end{array}$ & $\begin{array}{c}-1.035^{* *} \\
(0.438)\end{array}$ & $\begin{array}{c}-1.004 * * \\
(0.438)\end{array}$ \\
\hline HighVIX & $\begin{array}{c}2.264 * * * \\
(0.841)\end{array}$ & & & \\
\hline Debt Crisis & & $\begin{array}{c}16.732 * * * \\
(2.689)\end{array}$ & & \\
\hline Inflation Crisis & & & $\begin{array}{c}19.398 * * \\
(8.693)\end{array}$ & \\
\hline Currency Crisis & & & & $\begin{array}{c}0.647 \\
(0.544)\end{array}$ \\
\hline Observations & 637 & 395 & 395 & 395 \\
\hline Countries & 48 & 34 & 34 & 34 \\
\hline Country Fixed Effects & Yes & Yes & Yes & Yes \\
\hline Year Fixed Effects & No & Yes & Yes & Yes \\
\hline Adjusted R-squared & 0.375 & 0.781 & 0.781 & 0.776 \\
\hline
\end{tabular}


Table 4: GMM estimation of effect of central bank gold holdings on CDS spreads

The dependent variable in all columns is the logarithm of credit default swap (CDS) spreads on sovereign debt. All the explanatory variables, except for HighVIX, are lagged by one year. The second lags of Log CDS and Log CB Gold are used as instruments in the estimation. Standard errors for the two-step dynamic GMM estimation are presented in parentheses. '***', '**', '*' indicate significance at the $1 \%, 5 \%$ and $10 \%$ levels, respectively.

\begin{tabular}{|c|c|c|c|}
\hline & (1) & (2) & (3) \\
\hline L.Log CDS & $\begin{array}{c}0.761 * * * \\
(0.017)\end{array}$ & $\begin{array}{c}0.763 * * * \\
(0.040)\end{array}$ & $\begin{array}{c}0.812 * * * \\
(0.036)\end{array}$ \\
\hline Log CB Gold & $\begin{array}{c}-0.201 * * * \\
(0.046)\end{array}$ & $\begin{array}{c}-0.266 * * * \\
(0.097)\end{array}$ & $\begin{array}{l}-0.162^{*} \\
(0.094)\end{array}$ \\
\hline Log GDP per capita & $\begin{array}{c}1.047 * * * \\
(0.066)\end{array}$ & $\begin{array}{c}1.044 * * * \\
(0.096)\end{array}$ & $\begin{array}{c}0.994 * * * \\
(0.105)\end{array}$ \\
\hline Fiscal balance $\%$ of GDP & $\begin{array}{c}-0.046^{* * * *} \\
(0.008)\end{array}$ & $\begin{array}{c}-0.094 * * * \\
(0.010)\end{array}$ & $\begin{array}{c}-0.084 * * * \\
(0.013)\end{array}$ \\
\hline Sovereign debt $\%$ of GDP & $\begin{array}{c}-0.030 * * * \\
(0.003)\end{array}$ & $\begin{array}{l}-0.006 \\
(0.004)\end{array}$ & $\begin{array}{c}-0.014 * * * \\
(0.003)\end{array}$ \\
\hline GDP growth (\%) & $\begin{array}{c}0.051 * * * \\
(0.004)\end{array}$ & $\begin{array}{c}0.058 * * * \\
(0.004)\end{array}$ & $\begin{array}{c}0.064 * * * \\
(0.004)\end{array}$ \\
\hline Reserves as \% of imports & & $\begin{array}{c}0.011 * * * \\
(0.004)\end{array}$ & $\begin{array}{c}0.011 * * \\
(0.005)\end{array}$ \\
\hline Inflation (\%) & & $\begin{array}{c}0.137 * * * \\
(0.018)\end{array}$ & $\begin{array}{c}0.112 * * * \\
(0.014)\end{array}$ \\
\hline Curr. Acc. Bal. \% of GDP & & & $\begin{array}{c}0.006 \\
(0.013)\end{array}$ \\
\hline Rule of Law & & & $\begin{array}{c}0.544 \\
(0.337)\end{array}$ \\
\hline HighVIX & & $\begin{array}{c}1.351 * * * \\
(0.067)\end{array}$ & $\begin{array}{c}1.365^{* * * *} \\
(0.063)\end{array}$ \\
\hline Observations & 594 & 594 & 594 \\
\hline Number of Countries & 47 & 47 & 47 \\
\hline Country Fixed Effects & Yes & Yes & Yes \\
\hline Year Fixed Effects & No & No & No \\
\hline $\mathrm{AR}(1) \mathrm{p}$-value & 0.000 & 0.035 & 0.002 \\
\hline $\operatorname{AR}(2) p$-value & 0.251 & 0.186 & 0.528 \\
\hline $\begin{array}{l}\text { Hansen Test Chi2 } \\
\text { (p-value) }\end{array}$ & $\begin{array}{c}40.31 \\
(0.112)\end{array}$ & $\begin{array}{l}38.05 \\
(0.097)\end{array}$ & $\begin{array}{c}37.51 \\
(0.067)\end{array}$ \\
\hline
\end{tabular}

